\title{
Psykisk helsearbeid på internett: konsekvenser for normalitets- og identitetsdannelse hos ungdom
}

\author{
Anders Johan W. Andersen ${ }^{1}$ og Tommy Svensson ${ }^{2,3}$ \\ 1) Institutt for psykososial helse, Universitetet i Agder, Postboks 509, 4898 Grimstad \\ 2) Nordiska Högskolan för Folkhälsovetenskap, Göteborg \\ 3) Institutionen för beteendevetenskap och lärande, Linköping Universitet \\ E-post: anders.j.w.andersen@uia.no Telefon: 37233723
}

\begin{abstract}
SAMMENDRAG
Psykisk helsearbeid på internett øker i omfang, og verdsettes på grunn av bekvemmelighet, lave kostnader og muligheter for anonymitet. Artikkelen bygger på en kartlegging av norske og svenske nettbaserte eposttjenester for ungdom og unge voksne, og viser at det var 24 nettsteder som tilbød slike tjenester i 2009. Tjenestene hadde opphav i både offentlig og frivillig sektor. Flesteparten av sidene fra offentlig sektor tok utgangspunkt i eksisterende tjenestetilbud, og var en videreutvikling av tjenestene for å styrke tilgjengeligheten av psykisk helsetjenester. Andre sider oppsto som en konsekvens av FNs konvensjon av barns rettigheter. Størsteparten av sidene fra frivillig sektor ble utviklet som følge av et personlig og/eller fagpolitisk engasjement. Fire hovedtema for e-posttjenestene ble identifisert: 1) Kropp, kjønn og seksuell helse; 2) Informasjon og kontakt med voksne; 3) Rus og rusmidler; 4) Psykiske problemer.

Studien viser at nettjenestene argumenterer for at det er viktig for ungdoms psykiske helse at de blir inkludert og akseptert $i$ et fellesskap og at de opplever å bli respektert på egne premisser. Samtidig videreføres et ideal om det uavhengige og autonome mennesket, og nettjenestene formidler samlet sett et spenningsfylt budskap om at ungdom er avhengige av andre for å bli og forbli uavhengige individer. Psykisk helsearbeid på internett framstår som en måte å håndtere denne spenningen på, og muliggjør at ungdom kan håndtere en identitet som både avhengige og uavhengige mennesker. Studien viser forskjeller knyttet til begrepsforståelse, og peker på viktigheten av å utforske meningsinnholdet i psykisk helse nærmere.
\end{abstract}

Andersen AJW, Svensson T. Mental health services on the Internet. Nor J Epidemiol 2010; 20 (1): 5-14.

\section{ENGLISH SUMMARY}

The demand for Internet-based mental health services are increasing. The services are valued for their convenience, low cost and opportunities for anonymity. This article is based on a survey of Norwegian and Swedish Internet-based email services for adolescents and young adults. The objective was to explore the ways in which these services mould young people's view on normality and identity and how they contribute to mental health. 24 websites were systematically reviewed. Most of the sites from public sector derived from existing services and can best be understood as an attempt to enhance the availability of the same services for adolescents and young adults. Other sites were closely connected to the UN Convention of children's rights. A majority of the services from voluntary sector were developed as a result of initiatives taken by professionals or private persons. The email services focused different issues. A qualitative content analysis identified four main themes: 1) Body, gender and sexual health, 2) Information and contact with adults, 3) Drugs and substance abuse, 4) Mental problems.

In order to contribute to mental health amongst adolescents and young adults the services emphasise the importance of social inclusion and acceptation. At the same time the services maintain an ideal of the independent and autonomous human being. The services send out a message stating that young people are dependent on others to become and remain independent persons. Internet-based mental health services enables young people to deal with an identity as both dependent and independent. The study reveals differences regarding the concept of mental health, and emphasise the importance of exploring the concept and meaning of mental health more closely.

\section{INNLEDNING}

Etterspørselen etter psykisk helsearbeid på internett øker, og forskere antyder at folks vaner når det gjelder å søke og motta helsehjelp er i endring [1,2]. Flere studier viser at e-post er en spesielt populær tjeneste og attraktiv kommunikasjonsform når det gjelder psykisk helse [1-6]. Noen studier antyder sågar at folk foretrekker rådgivning via e-post framfor andre tilnærmingsformer [3,4]. Bekvemmelighet framstår som en av de største fordelene først og fremst fordi folk sparer tid og penger [1,6-9]. Tjenestene blir særlig verdsatt i områder med spredt bebyggelse og lange avstander til offentlige tjenester [10-12]. Slik sett bidrar internett til 
å øke tilgjengeligheten til psykiske helsetjenester, minimere tiden folk bruker for å oppsøke hjelp og redusere ventelister [1,7]. Tjenestene framstår kostnadseffektive både for brukerne og tilbydere $[1,13]$. Studier viser også at brukerne får bedre tid til å uttrykke sine behov $[7,14,15]$, og gir mer passende tilbud til mennesker som foretrekker skriftlig kommunikasjon [8].

Intervensjonsstudier viser at nettbaserte tjenester kan redusere stigma, dempe opplevelser av isolasjon hos brukere, og øke tilgjengeligheten av profesjonelle [16, 17]. Enkelte studier antyder at barn og unge får bedre psykisk helse etter å ha brukt tjenester på nett [5]. Til tross for antagelser om det motsatte viser studier at bruk av helsetjenester på nett øker kontakten med ordinære tjenester [18], og fungerer komplementære til mer tradisjonelle psykiske helsetjenester [3,7,16,17, 19]. Internettbaserte tjenester bør imidlertid ikke kun betraktes som et første skritt på veien til psykisk helsevern. Studier viser at internett også tiltrekker seg folk som er misfornøyde med tjenestene og ønsker en ny vurdering [8], og/eller har en form for mistillit til spesialisthelsetjenesten og ønsker en helt annen hjelp [16].

Anonymitet framstår som en annen sentral fordel for brukerne av nettbaserte helsetjenester, og flere studier viser at noen foretrekker tjenester over internett framfor tilbud ansikt til ansikt [1, 6-9]. Det antydes at brukerne svarer mer oppriktig og er mer komfortable med å kommunisere om psykisk helse når tjenesten er anonym $[1,7,12]$. Andre forskere uttrykker bekymring for nettbaserte tjenester av samme grunn [20]. De hevder at folk oppfordres til for rask selvavsløring på grunn av anonymiteten som tilbys over nettet, og er bekymret over mangelen på terapeutiske kontroll i disse tjenestene. I en gjennomgang av vitenskapelige artikler framkommer det også at nettbaserte tjenester ikke kan erstatte kontakt ansikt-til-ansikt [1]. Valentine og Holloway [21] har på sin side gjennomført en studie om forholdet mellom barn og unges identitet og sosiale nettverk on- versus off-line. Deres funn peker mot at nettbaserte tjenester gir barn og unge bedre kontroll over egen identitet fordi asynkron kommunikasjon gir dem tid til å tenke på hva de vil si og hvordan de ønsker å presentere seg selv. De argumenterer for de unges on- og off-line verdener konstituerer hverandre gjensidig, og fungerer berikende for deres liv og utvikling.

Når det gjelder brukere av nettbaserte psykiske helsetjenester, så viser noen studier en kvinnelig dominans [1,22]. Thayer og Ray [23] finner imidlertid ingen signifikante forskjeller i kjønn, og det synes vanskelig å konkludere entydig. Det er mer pålitelige resultater når det gjelder alder, og flere studier framholder at ungdom og unge voksne er de hyppigste brukerne $[4,14]$. Det er en viss variasjon i dette spørsmålet også, og den mest betydningsfulle sammenhengen synes å være relatert til varigheten i bruken av internett. Hyppig bruk av internett generelt øker også bruken av nettbaserte tjenester [23]. Flere forskere argumenterer imidlertid for at psykisk helsearbeid på internett er spesielt egnet for unge mennesker, og anbefaler økt tilgang til disse tjenestene for ungdom [5,6,24,25]. Det er samtidig vanskelig å entydiggjøre forskningsresultatene innen dette feltet dels fordi feltet er ungt og ennå mangelfullt utforsket, og dels fordi det framstår som et lite ensartet felt. Internett-baserte tjenester er ingen entydig gruppe helsetjenester, men har stor variasjon både $\mathrm{i}$ eierstruktur, design, tjenesteprofil og innhold. Denne kunnskapssammenstillingen er skrevet med utgangspunkt i 102 forskningsartikler, men avgrenset til å fokusere det som synes mest relevant og treffende for denne studien. Disse artiklene har framkommet etter et systematisk søk på databasene Pubmed, ISI Web of Knowledge, ERIC, Embase, Cochrane reviews, Medline, Norart, Swemed og British Nursing Index. Søkeordene som ble brukt, var "mental health" i kombinasjon med enten "Internet based service", "Internet" eller "Electronic mail". Søket ble avgrenset til artikler på dansk, engelsk, norsk og svensk etter år 2000.

Historieforskning viser at spørsmål om psykisk helse og uhelse er tett sammenvevd med sosiale og kulturelle forhold [26-29]. Dette understøttes også av teoretiske analyser [30], og helsepolitiske dokumenter [31]. Vitenskapsfilosofen Ian Hacking [32] betegner psykiske problemer som flyktige fenomener som oppstår på bestemte steder og tider. Han argumenterer for at våre beskrivelser fungerer som interaktive kategorier som i seg selv både skaper og opprettholder tanke-, følelses- og samhandlingsmønstre [32,33]. I et slikt perspektiv blir psykisk helse og uhelse både fenomener som "er", og som skapes og endres med tid, sted og kultur. På lignende måter vil også aktuelle nettsteder både være et uttrykk for helseproblemer som eksisterer i befolkningen, og bidra til å opprettholde og skape forestillinger om psykisk helse og uhelse. Katsumata et al. [34] peker for eksempel på klare sammenhenger mellom tid tilbrakt på internett på jakt etter informasjon om selvmord og selvskade, og personens opplevelser av angst og emosjonelle plager. De Wattignar og Read [35] viser at finansiering av legemiddelindustrien påvirker innholdet på ulike websider i en retning som skal øke salg av legemidler. Carlberg [36] har på et mer generelt grunnlag dokumentert hvordan kapitalinteresser former psykisk helsefeltet og bidrar til å øke andelen mennesker med diagnostiserte psykiske problemer. Det kan med andre ord være interessant å undersøke hvilke nettjenester som finnes, hvem som har initiert og styrer tjenestene og hvilke tema som fokuseres. Med utgangspunkt i en kartlegging av nettbaserte e-posttjenester til barn, ungdom og unge voksne i Norge og Sverige diskuteres hvordan psykisk helsearbeid på internett kan forme forståelser av normalitet og identitet hos ungdom. Følgende to forskningsspørsmål danner grunnlaget for kartleggingen og den påfølgende diskusjonen:

\footnotetext{
1) Hvilket opphav har nettbaserte e-posttjenester til barn, ungdom og unge voksne i Norge og Sverige? 2) Hvilke temaer fokuseres på disse nettsidene?
} 
Tabell 1. Oversikt over utvalget.

\begin{tabular}{|c|c|c|c|}
\hline \multicolumn{2}{|c|}{ Norsk utvalg } & \multicolumn{2}{|r|}{ Svensk utvalg } \\
\hline Nettadresse & Ansvarlig utgiver & Nettadresse & Ansvarlig utgiver \\
\hline www.barnogunge.no & $\begin{array}{l}\text { Arbeiderbevegelsens rus og } \\
\text { sosialpolitiske forbund }\end{array}$ & www.bup.nu & $\begin{array}{l}\text { Barne- og ungdomspsykiatri i } \\
\text { Stockholm, Stockholms länsting }\end{array}$ \\
\hline $\begin{array}{l}\text { http://www.barneombudet.no } \\
\text { /klarmelding/ }\end{array}$ & Barneombudet & www.bris.se & Barnens rätt i samhället (BRIS) \\
\hline www.jentevakta.com & \begin{tabular}{|l|} 
Jentevakta (Grunnlagt av \\
Krisesenteret i Trondheim)
\end{tabular} & http://busta.atsub.se & $\begin{array}{l}\text { BUSTA - stöd till sexuelt utsatta } \\
\text { unga }\end{array}$ \\
\hline www.klara-klok.no & Nordland fylkeskommune & www.drugsmart.com & $\begin{array}{l}\text { Centralförbundet för alkohol och } \\
\text { narkotikaupplysning (CAN) }\end{array}$ \\
\hline www.korspahalsen.no & Røde Kors & www.heder.nu & $\begin{array}{l}\text { Riksförbundet för sexuellt } \\
\text { likaberättigande (RFSL) Skåne }\end{array}$ \\
\hline www.morild.org & $\begin{array}{l}\text { Avdeling for barn og ungdoms } \\
\text { psykiske helse ved Sørlandets } \\
\text { Sykehus HF }\end{array}$ & www.linje59.se & $\begin{array}{l}\text { Riksförbundet för sexuellt } \\
\text { likaberättigande (RFSL) Ungdom }\end{array}$ \\
\hline www.rustelefonen.no & $\begin{array}{l}\text { Rusmiddeletaten i Oslo } \\
\text { kommune }\end{array}$ & www.rus-riks.se & $\begin{array}{l}\text { Rikesförbundet Ungdom för Social } \\
\text { Hälsa }\end{array}$ \\
\hline www.suss.no & $\begin{array}{l}\text { Senter for ungdomshelse, samliv } \\
\text { og seksualitet (SUSS) }\end{array}$ & www.snorkel.se & $\begin{array}{l}\text { Barne- og ungdomspsykiatrien i } \\
\text { Uppsala }\end{array}$ \\
\hline www.ung.no & $\begin{array}{l}\text { Barne-, ungdoms - og } \\
\text { familiedirektoratet (Bufdir) }\end{array}$ & www.spesungdom.se & SPES:ungdom \\
\hline www.ungdomstelefonen.no & Skeiv ungdom & www.tjejzonen.se & Tjejzonen \\
\hline www.utekontakten.no & Utekontakten i Bodø kommune & www.umo.se & Sjukvårdsrådgivningen SVR AB \\
\hline www.wandasenteret.no & Frivillighetssentralen i Bodø & www.ungdomar.se & UMIT Sverige AB \\
\hline
\end{tabular}

Epidemiologisk forskning har som hovedformål "å studere sykdommers forekomst og dødelighet, finne risikoen for sykdom og identifisere personer med høy risiko for sykdom" [37, s. 33]. Denne studien gir kunnskap om forhold som kan fremme eller hemme ungdommers psykiske helse ut fra et resonnement om at spørsmål knyttet til psykisk helse kontinuerlig er i bevegelse og formes av samtiden.

\section{UTVALG OG ANALYSE}

Første skritt i kartleggingsarbeidet var å definere søkeord og søkemotor. Innledningsvis prøvde vi ut ulike søkeord for å sjekke ut antall treff. Vi søkte for eksempel med ordene "psykisk helse" i kombinasjon med "epost". Det gav over 300.000 treff, og ble for uhåndterbart. Andre kombinasjoner gav på den andre siden for magre resultater. På norsk valgte vi å bruke ord som gikk igjen i de norske nettjenestene www. korspahalsen.no og www.sidetmedord.no. Søkeordene ble derfor "psykisk helse" i kombinasjon med enten "meldingstjeneste", "svartjeneste" eller "mailtjeneste". De svenske søkeordene ble definert i etterkant av det norske søket, og var inspirert av samme søkeord. Disse kombinasjonene gav imidlertid ikke samme treffsikkerhet på svensk. Vi utvidet derfor de svenske søkeordene, og tok da utgangspunkt i ord som ble brukt på svenske nettsider. De svenske søkeordene ble derfor "psykisk hälsa" i kombinasjon med enten "nättjänst", "mailtjänst", "mejltjenst", "mail nätforum", "chatte mail forum" eller "jourmail". Google ble valgt som søkemotor. Avslutningsvis gjennomførte vi imidlertid et enkelt søk ved hjelp av søkemotoren Kvasir. Målet var å sjekke ut om denne søkemotoren ville tilføre studien flere og andre treff. Dette var ikke tilfelle.

Søket ble gjennomført i 2009, og resulterte i 502 treff. Alle treffene ble kort vurdert. Listen over nettsteder ble raskt redusert ved å ekskludere irrelevante og overlappende treff. Utvalget ble utvidet ved at anbefalinger til andre nettsteder nevnt på relevante nettsteder ble inkludert. Denne arbeidsmåten er noen ganger referert til som "snowball sampling" [38]. Ambisjonen var å inkludere alle nettsteder som hadde en e-posttjeneste av noe slag. Denne prosessen resulterte i 69 norske og 82 svenske nettsteder. Disse nettstedene ble grundig undersøkt, og kun nettsteder som hadde en tilsiktet e-posttjeneste rettet mot barn, ungdom og unge voksne ble inkludert i utvalget.

Dette stilte oss overfor noen utfordringer. Flere nettjenester var aktuelle, men samtidig ikke avgrenset til barn, ungdom og unge voksne. Enkelte nettsteder presiserte for eksempel at tjenestene var for alle. Dette gjaldt for eksempel enkelte nettsteder knyttet til seksuelle overgrep (www.incest80057000.no) og selvskading/spiseforstyrrelser (www.shedo.org). Andre nettsteder var åpenbart relevant for spørsmål angående barn og unge, men e-posttjenesten var primært rettet mot foreldre eller andre voksne (www.vfb.no og www.elevhalsan.se). Vi valgte å avgrense utvalget til nettsteder der e-posttjenestene var eksplisitt rettet mot barn, ungdom og/eller unge voksne. Da sto vi igjen med et utvalg på 24 nettsteder - 12 norske og 12 svenske (Tabell 1).

Det var to hovedtrekk ved formuleringer omkring 
målgruppe i utvalget. Den ene halvparten (11 nettsteder) hadde mindre eksakte og mer forhandlingsbare formuleringer omkring målgruppen, og skrev at sidene var rettet mot barn, ungdom og/eller unge voksne: " $D u$ som är ung kan anonymt skicka in frågor till oss om psykiska problem och bekymmer. Vi svarar inte på frågor från föräldrar eller andra vuxna" (www.bup.nu). Den andre delen av utvalget (13 nettsteder) avgrenset målgruppen klart i kronologisk alder. Enkelte av disse sidene oppgav ingen nedre aldersgrense, men skrev at e-posttjenesten var rettet mot personer under en viss alder, eller at nettsiden var beregnet for personer opp til en viss alder: "Till BRIS-mejlen kan alla som är under 18 år skriva" (www.bris.se). Andre opererte med et klart definert aldersspenn: "ung.no er rettet mot ungdom mellom 13 og 20 år fordi dette er en periode som scerlig preges av valg og endring" (www.ung.no). Aldersspennet varierte fra 6 til 35 år i utvalget, men de fleste av sidene oppgav målgruppen til å være mellom 10 og 25 år.

Materialet ble analysert med utgangspunkt i kvalitativ innholdsanalyse $[38,39]$. De to forskningsspørsmålene ble brukt som metodiske brekkstenger i analyseprosessen for å hente ut data fra nettsidene, og dannet grunnlaget for kategoriseringen av innholdet. Teksten på de utvalgte nettsidene ble grundig undersøkt, og vedlagte årsrapporter og annen aktuell dokumentasjon ble gjennomgått. I enkelte tilfeller ble også ansvarlig utgiver kontaktet per e-post og bedt om ytterligere informasjon. Den tilgjengelige informasjonen ble samlet og sortert $\mathrm{i}$ et eget Word-dokument under hovedkategoriene opphav og tema. I neste trinn ble informasjonen under hver hovedkategori gjennomgått, og innholdet for hvert nettsted ble fortettet og redusert. Dernest ble det søkt å finne mønstre i materialet utfra de fortettede enhetene, og identifisere undergrupper under hver hovedkategori. Hver nettside ble til slutt merket med undergruppe, og samlet $\mathrm{i}$ et Excel-dokument. Dette gjorde sammenligninger på tvers av utvalget enklere. Kvalitativ forskning er en fortolkende vitenskapelig aktivitet, og inspirert av Alvesson og Sköldberg [40] blir funnene presentert og diskutert under overskriftene "Tolkning" og "Refleksjon".

\section{TOLKNING}

Internett-baserte tjenester er i utgangspunktet tilgjengelig for alle som kan forstå språket, og de aller fleste tjenestene i denne studien har et nasjonalt nedslagsfelt. To tjenester har imidlertid mer regionale siktemål, og søker på den måten å avgrense målgruppen (www.bup. nu \& www.utekontakten.no). "Vi har ikke tekniske muligheter til å se hvor innsenderne kommer fra, men er nokså sikre på at et flertall av brukerne er Bodøungdom." (Personlig e-post fra Randi Helen Albertsen ved www.utekontakten.no, 22. april 2009). Slik oppsummerer lederen av en av disse tjenestene erfaringene med en geografisk avgrensning av målgruppe.
Felles for alle nettsidene er at de gir tilgang til informasjon. Mengden av informasjon varierer, men en både mulig og rimelig fortolkning tilsier at nettsidene inngår i en folkeopplysningstradisjon. Dette understøttes ved at spørsmål og svar legges åpent ut på nettet på de fleste sidene. Innsenderne blir også tydelig informert om denne praksisen. Hensikten med en slik offentliggjøring er imidlertid i liten grad begrunnet på nettsidene. Den synes imidlertid å være styrt av et ønske om å skape muligheter for gjenkjennelse og reduksjon av sosialt stigma. Det kan også handle om mer praktiske forhold. "Tenk at det er mange som trenger hjelp, derfor kan du stille max 5 spørsmål i måneden. Sjekk om andre har spurt om det samme. Sjansen er stor for at du finner svar på det du lurer på blant spørsmål som ligger ute på ung.no/oss" (www.ung. no). En offentliggjøring av spørsmål og svar kan med andre ord også redusere pågangen av e-post fra potensielle innsendere fordi folk kan lese og lære av andres spørsmål og svar. Samlet sett får nettsidene en helsefremmende profil gjennom en vektlegging på erfaringsog kunnskapsdeling både fra innsendere og svarere.

Anonymitet er et ankerfeste for disse tjenestene, og de fleste tjenestene bruker moderne krypteringsteknologi slik at innsenderne ikke kan spores opp. Noen få tjenester hadde ikke dette, og baserte seg på at innsendere sendte e-post fra egen adresse (eks. www. tjejzonen.se). Disse tjenestene offentliggjorde ikke epostene, og la sterkere vekt på at de fungerte som en personlig og individuell oppfølgings- og rådgivningstjeneste. På enkelte nettsider utgjør e-posttjenesten kun en liten og litt gjemt del av tilbudet (eks. www.rusriks.se), mens andre sider har svartjenesten som selve omdreiningspunktet (eks. www.ungdomstelefonen.no). Hvem svarer så på disse e-postene fra ungdom og unge voksne? Det varierer. Halvparten av tjenestene er bemannet av fagfolk, mens resten av "svarerne" fordeler seg på lekfolk, personer med egen erfaring innen temaområdet eller en blanding av disse gruppene.

Denne innledende fortolkningen av utvalget gir et oversiktsbilde over tjenestene. Den videre tolkningen av data er strukturert i henhold til studiens to forskningsspørsmål, og er følgelig inndelt i en seksjon som fokuserer opphav og motivasjonsgrunner og en seksjon som tar for seg temaområder. Det var generelt sett stort samsvar i både opphav og tema mellom landene.

\section{Opphav og motivasjonsgrunner}

Det var vanskelig å spore opphavet til alle nettstedene, og avdekke den bakenforliggende motivasjonen for å starte en egen e-posttjeneste. For flere av stedene fulgte e-posttjenesten som en videreføring av en telefontjeneste, mens andre ble opprettet mer på bakgrunn av de mulighetene som åpnet seg i kjølvannet av utbredelsen av internett. Enkelte steder hadde sitt opphav i offentlig sektor og utvikling av offentlige tjenester, mens andre hadde en sterkere tilknytning til frivillige organisasjoner. Kun en nettside hadde utgangspunkt $\mathrm{i}$ privat sektor. Dette gjenspeiles også i denne framstil- 
lingen. Tre hovedgrupper av opphav ble identifisert. De to første gruppene har i hovedsak sitt utspring fra offentlig sektor, mens den tredje gruppen med et unntak stammer fra frivillig sektor.

\section{FNs konvensjon om barns rettigheter}

FNs konvensjon om barns rettigheter var utgangspunktet for fire nettsteder i utvalget. Barneombudet $\mathrm{i}$ Norge har en særstilling i denne sammenhengen siden det $\mathrm{i}$ henhold til norsk lov skal påse at norsk forvaltningspraksis er i samsvar med de forpliktelser Norge har etter barnekonvensjonen. De tre andre nettstedene har også sitt opphav i barnekonvensjonen, og i tillegg til å vise til denne konvensjonen generelt nevnes artikkel 12, 13 og 17 i særdeleshet. Alle disse tjenestene har med andre ord et opphav som ikke eksplisitt er knyttet til ungdom og psykisk helse, men der psykisk helse er innvevd i virksomheten. Brisrapporten for 2010 (bris.se/) viser for eksempel tydelig at tjenesten i stor grad preges av spørsmål med relasjon til psykisk helse.

\section{Videreutvikling av eksisterende tjenester}

Syv nettsteder hadde sitt opphav i offentlige helse- og sosialtjenester, og ble først og fremst etablert for å utvide og øke tilgjengeligheten av eksisterende tjenestetilbud. Sidene oppgir oftest at nettsiden og eposttjenesten fungerer som et supplement til andre tjenester, og flere oppgir at de skal vise vei inn til de mer ordinære tjenestene. Enkelte peker også på sidenes funksjon i det forebyggende og helsefremmende arbeidet overfor barn, ungdom og unge voksne, og fungerer som et første møte med ungdommene. "Vi vet at mange unge bruker mye tid på nettet, og det vil kanskje vare den eneste måten å komme i kontakt med mange som vi ikke vil treffe for eksempel på felt. Kommunikasjonen på internett er en ny form for sosialt samver, et sted hvor de både oppholder seg og utvider viktige sosiale nettverk." (Årsrapport for Utekontakten i Bodø for 2008, s. 4). E-posttjenesten gir slik sett mulighet for variasjon i det offentlige helse- og sosialtilbudet, og finansieres og drives av virksomheter på enten statlig, regionalt og/eller lokalt nivå.

\section{Personlig og fagpolitisk engasjement}

13 nettsteder ble i hovedsak etablert som følge av et personlig og/eller fagpolitisk engasjement. Disse sidene hadde uttalte ambisjoner om å påvirke og endre forhold i samfunnet. E-posttjenestene fungerer ofte som et supplement til eksisterende tilbud, men kan også framstå nyskapende og etablere nye tilbud som ikke dekkes tilfredsstillende av eksisterende offentlige tjenester.

Enkelte av disse sidene knyttes i stor grad til privatpersoner og deres personlige erfaringer: "Paal-Andre Grinderud startet Wandasenteret. Paal-Andre vokste opp $i$ et hjem preget av alkoholmisbruk. Gjennom boken "Alene - nå igjen" fikk han gitt barn av alkoholikere en stemme og et ansikt" (www.wandasenteret. no). Også fagpersoner står bak enkelte nettsteder, og disse ble da etablert pga. et særlig engasjement. "Høsten 1999 togs initiativet till att bygga en sajt på nätet där specialistutbildade experter som läkare, psykologer, barnmorskor, SYO-konsulenter etc kunde svara på anonyma ungdomars frågor rörande bl.a. kroppen, sexlivet, kompisar, föräldrar, utbildninger, jobb etc." (www.ungdomar.se).

Andre sider ble knyttet tettere opp til frivillige organisasjoner, og deres aktivitet (eks. www.rus-riks.se). Noen viste til forskningsrapporter som bakgrunnen for etableringen av nettsidene og/eller e-posttjenesten (eks. www.ungdomstelefonen.no). Dette var landsdekkende frivillige organisasjoner som oftest understreket sin uavhengighet til offentlige myndigheter, og viste til at de er partipolitisk uavhengige og religiøst nøytrale virksomheter.

\section{Temaområder}

Det var utfordrende å gruppere nettstedene ut fra tema. Enkelte steder strittet mot en slik kategorisering, og kunne med en viss gyldighet plasseres under flere overskrifter. Ut fra en grundig og gjentagende gjennomgang av innholdet på de ulike nettstedene $\mathrm{i}$ utvalget har vi likevel funnet det mulig å skille ut fire hovedgrupper.

\section{Kropp, kjønn og seksuell helse}

Ni nettsteder fokuserte på spørsmål angående kropp, kjønn og seksuell helse. Dette framstår totalt sett som det mest omfattende temaområdet i utvalget. Samtidig var det mulig å identifisere fire ulike undertema $\mathrm{i}$ denne gruppen. Alle sidene var åpne for alle undertema, men vektla samtidig temaene ulikt. Dette går fram av presentasjonen under.

a) Informasjon

Tre sider besvarte spørsmål som i hovedsak berørte kropp, pubertet, sex, prevensjon, graviditet og abort. Tjenestene var orientert mot informasjon, og var alle fullfinansiert av det offentlige. Den svenske siden UMO kan tjene som illustrasjon for disse sidene: "Syftet med sajten är att göra det lättare för unga att hitta relevant, aktuell och kvalitetssäkrad information om sex, hälsa och relationer" (www.umo.se).

b) Skeive sider

To nettsider, en i hvert land, fokuserte utelukkende på spørsmål angående homo-, bi- og transseksualitet. Begge hadde opphav i frivillige organisasjoner, men ble i stor grad finansiert gjennom offentlige midler. De ønsket å bidra med informasjon og være et lett tilgjengelig hjelpetilbud for unge "skeive". Den norske nettsiden www.ungdomstelefonen.no vitner om ambisjoner om å påvirke både identitetsdannelse og forståelser av normalitet:

\section{"Homofiles Ungdomstelefon skal:}

- styrke unge LHBT sin selvfølelse, herunder psykisk helse (...)

- bidra til å avklare spørsmål rundt egen identitet, gjennom blant annet å normalisere det å vare skeiv" 
c) Om å være jente

"Att stärka ung kvinnors självkänsla och självtillit och fokusera på varje tjejs postitiva kraft är ett led $i$ vårt övergripande mål att förebygga psykisk ohälsa" (www.tjejzonen.se). Dette sitatet illustrerer tema og formål for to nettsider i utvalget. De fokuserte på jenter og deres vilkår i samfunnet. Sidene hadde til hensikt å bryte uheldige rollemønstre i samfunnet, redusere undertrykking og overgrep mot jenter, og fremme jenters kreativitet, selvstendighet og styrke deres kollektive selvbevissthet og selvtillit.

\section{d) Krenkelser og overgrep}

To svenske nettsteder gav tilbud om informasjon og bistand til barn og ungdom som hadde blitt utsatt for seksuelle krenkelser og/eller overgrep. Begge sidene hadde sitt opphav i frivillige organisasjoner, og pekte på behovet for å ivareta disse problemstillingene bedre i samfunnet. En av sidene fokuserte eksplisitt på hedersrelatert vold og krenkelser, og pekte på viktigheten av å ta disse spørsmålene på alvor: "Grundläggande för alla delar $i$ verksamheten är utgångspunkten att en trygg och välintegrerad sexuell identitet är nödvändig för god psykosocial hälsa och ett individuellt förankrat säkrare sex beteende" (www.heder.nu).

\section{Informasjon og kontakt med voksne}

Fem nettsider - tre norske og to svenske - anlegger et bredt og åpent perspektiv både på nettstedet generelt og e-posttjenesten spesielt. De sikter mot å ivareta barn og ungdoms behov og interesser generelt, gi informasjon om rettigheter og tilby kontakt med voksne. Barn og ungdom inviteres til å skrive inn om det de er opptatt av: "Det kan handle om vad som helst. Du bestämmer!" (www.bris.se). Flere av sidene omtaler seg selv som opinionsdannere og sikter mot å forsterkere barns erfaringer og meninger i samfunnet. Tanken er at "alle barn skal har rett til å uttrykke sin mening, og å få den respektert $i$ spørsmål som angår dem" (www. korspahalsen.no). De ønsker å legge til rette for dialoger på internett der barn og ungdom henter informasjon om samfunnet fra nettstedene, mens nettstedene på sin side bringer barns og ungdoms stemmer og erfaringer tilbake til samfunnet. Barns rett til å uttrykke seg og bli hørt står sentralt. Det samme gjør visjonen om at barn og ungdom skal få muligheter til å treffe informerte valg om eget liv og helse. Disse sidene er ikke eksplisitt rettet mot ungdom og psykisk helse, men har dette som et av flere temaområder. Det synes også tett sammenvevd med tjenestenes overordnede helsefremmende profil [se eks. 41].

\section{Rus og rusmidler}

Fire nettsteder - tre norske og ett svensk - forenes i sitt hovedfokus på barn og ungdoms forhold til rus og rusmiddelbruk. Alle sidene formidler informasjon om rus og rusmisbruk, men to norske sider retter oppmerksomheten mot barn og ungdom som lever i familier der en eller begge foreldre misbruker rusmidler.

"Går du også rundt og engster deg fordi mamma eller pappa drikker for mye, bruker piller eller narkotika?
Da er du ikke alene! Titusenvis av barn og unge under 18 år bor $i$ en familie hvor minst en person misbruker alkohol, tabletter eller andre rusmidler. Dette er ikke din skyld, det er en sykdom!" (www.barnogunge.no)

Disse sidene sikter mot å være til hjelp og støtte for barn og unge som trenger en voksen å snakke med, og dele sine bekymringer og tanker med. De to andre sidene retter seg mer direkte mot ungdom og unge voksne, tilbyr veiledning knyttet til rus, men også mer undervisningsrettede opplegg.

\section{Psykiske problemer}

Det som kjennetegner disse seks nettstedene er en mer eksplisitt invitasjon til å skrive om psykiske problemer og psykiske vansker. Det er "psykisk" i en eller annen forstand, og nettsidene formidler en tilhørighet til det som kan betegnes som psykisk helsefeltet. Dette er for eksempel gjenkjennelig i sidene til Barne- og ungdomspsykiatrien i Stockholm: "Du kan skriva anonymt till oss och fråga om olika slags svårigheter eller psykiska problem" (www.bup.nu). Andre nettsteder er mer spisset i profilen. To nettsteder løfter fram ungdoms rolle som pårørende enten i relasjon til foreldre (www.morild.org) eller søsken (www.spesungdom. se), mens ett nettsted tilbyr informasjon og muligheter for å stille spørsmål angående nedstemthet, uro, angst og stress (www.snorkel.se). Brukerorganisasjonen Riksforbundet Ungdom för Social Hälsa (RUS) driver et nettsted for ungdom med psykiske problemer, og kjemper her for at unge mennesker som sliter psykisk "genom hjälp $i$ ett tidigt skede och under tillräckligt lång tid - ska få möjlighet till personlig utveckling och ett gott liv på sina egna villkor". De tilbyr ungdom kontakt med andre mennesker som har erfaring med psykisk uhelse, og inviterer til deltakelse i et arbeid som motvirker utenforskap og øker "möjligheterna till återhämtning för den som drabbas av social eller psykisk ohälsa" (www.rus-riks.se).

\section{REFLEKSJON}

Studien viser variasjon når det gjelder opphav og temaområder i psykisk helsearbeid på internett. Det handler om kropp, pubertet, familieforhold, kjønn, seksualitet, legning, forelskelse, rus og rusmisbruk, uro, angst, depresjon, selvmord og vanskelige liv generelt. Selv om ungdoms rolle som pårørende til foreldre som sliter i en eller annen forstand nok er noe tydeligere $\mathrm{i}$ dette materialet, og adferdsvansker ditto mindre synlig, er temaområdene gjenkjennelig fra nyere norsk forskning omkring psykososiale utfordringer for ungdom [42]. Adferdsproblemer blir i mange sammenhenger beskrevet som eksternaliserende vansker, og defineres oftest som problematisk forst og fremst av personer rundt ungdommen og mindre av ungdommen selv $[42,43]$. Ut fra et slikt resonnement blir det mulig å forstå at nettsider som er rettet mot ungdommene selv, i mindre grad løfter fram adferdsproblemer som et temaområde. 
I denne delen av artikkelen vil vi reflektere over studiens mulige konsekvenser for forståelser av normalitets- og identitetsdannelse hos ungdom. Avslutningsvis vil vi peke på noen metodiske dilemmaer som både angår studiens troverdighet og gyldighet, men som også har relevans for diskusjoner omkring ungdom og psykisk helse.

\section{Normalitetspolitikk}

Det er mulig å argumentere for at enkelte nettsteder arbeider aktivt for å inkludere en større variasjon av menneskelige uttrykk innenfor rammen av det normale, og derigjennom skape et større rom for et ikkepatologisert menneskelig mangfold. "Homofiles Ungdomstelefon skal bidra til å avklare spørsmål rundt egen identitet, gjennom blant annet å normalisere det å vaere skeiv" (www.ungdomstelefonen.no). Ambisjonen er å anerkjenne ungdoms ulike uttrykk som normale, og derigjennom motvirke tendenser til "utanförskap och öka möjligheterna till återhämtning för den som drabbas av social eller psykisk ohälsa" (www.rusriks.se). Denne tilnæringen bunner i en forståelse for at psykisk uhelse skapes i møter med et "uforstående" og lite aksepterende samfunn. Nettstedene og e-posttjenestene inngår en kamp for å endre samfunnet slik at alle blir akseptert på egne premisser.

Det er også mulig å identifisere en litt annen normalitetsforståelse i utvalget. Denne forståelsen har utspring i en medisinsk sykdomsmodell. "Dette er ikke din skyld, det er en sykdom!" (www.barnogunge.no). Folks utfordringer med vanskelige liv blir her forankret i hvert enkelt menneske. Det er ikke familiens eller samfunnets manglende aksept som skaper uhelse. Omgivelsene får derimot et særlig ansvar for å tilrettelegge og inkludere mennesker som har psykiske funksjonshemninger. Dette videreføres i et resonnement om at det er vanlig å ha problemer med den psykiske helsen, og at det er normalt og lurt å søke hjelp for slike plager. Det blir da viktig å lære om egen psykisk helse også for å unngå å bli syk. "På den här sidan kan du läsa om vad nedstämdhet, oro/ångest och stress är, hur det kan kännas och du för också tips på vad du kan göra om du mår dåligt, känner dig stressad eller har dåligt självförtroende" (www.snorkel.se). Det er med andre ord en mer individorientert forståelse som tilbys.

Begge forståelsene samler seg imidlertid rundt et felles budskap: Det er viktig for ungdoms psykiske helse at de blir inkludert og akseptert $i$ et fellesskap og at de her opplever å bli respektert på egne premisser. Nettstedene sikter på ulike måter å påvirke samfunnets forståelser av hva som er vanlig og må aksepteres, og utøver et normalitetspolitisk arbeid. De kjemper for at ungdom skal bli anerkjent $\mathrm{i}$ og av et ikke-identifiserbart storsamfunn, og gjør det mulig å argumentere for en forståelse om at ungdommers psykisk helse er avhengig av en slik kulturell anerkjennelse.

\section{Identitetsdannelse}

Samtidig ble det understreket at ungdomstiden var en periode i livet preget av valg og endring (www.ung. no). Flere nettsteder hadde derfor fått eller gitt seg selv et mandat om å fungere identitetsstyrkende gjennom å tilby relevant, aktuell og kvalitetssikret informasjon slik at ungdom selv kunne ta informerte valg. Argumentasjonen for dette ble $\mathrm{i}$ hovedsak forankret $\mathrm{i}$ et individ- og rettighetsorientert perspektiv. Enkelte nettsteder forankret tjenestene $\mathrm{i}$ barnekonvensjonen og framhevet enkeltmenneskets rettigheter. Andre steder vektla også et budskap om at ungdom skulle få muligheter til et "gott liv på sina egna vilkår" (www.rusriks.se), og ikke føle skyld eller påta seg ansvar for andres psykiske helse heller ikke som pårørende til andre (www.morild.org). Det er mulig å argumentere for at nettsidene derigjennom fremmet et ideal om det uavhengige og autonome mennesket. Dette er i så fall helt i tråd med målsettingen i opptrappingsplanen for psykisk helse i Norge; "... målet med tjenestetilbudene til mennesker med psykiske lidelser må vare å fremme uavhengighet, selvstendighet og evnen til å mestre eget liv" [44, s. 6]. Det ligger en mulig spenning i dette. På den ene siden kan det argumenteres for at nettstedene fremmer en forståelse av ungdom som uavhengige og autonome individer som skal forvente respekt for sin egenart. Samtidig er vilkårene for deres psykiske helse og mulighetene for livsmestring avhengig av en anerkjennelse fra et fellesskap. Litt forenklet kan man samlet sett hevde at ungdommer er avhengige av andre for å bli og forbli uavhengige individer.

Psykisk helsearbeid på internett kan være en måte å håndtere denne spenningen på, og derigjennom tilby en forklaring på attraktiviteten ved internettbaserte tjenester i psykisk helsearbeid. De tilbyr et fellesskap der deltakerne anonymt kan vise sin sårbarhet og avhengighet til andre on-line, og samtidig opprettholde sin uavhengighet off-line. Internett muliggjør med andre ord at ungdom kan håndtere en identitet som både avhengig og uavhengig av andre mennesker. Det vil være av samfunnsmessig betydning at disse verdenene konstituerer hverandre gjensidig, fungerer berikende og styrker ungdoms muligheter for mestring [21]. Mennesker må ikke bare blir anerkjent on-line, men også bli anerkjent og ikke minst anerkjenne andre off-line. Det er en utvikling som er av betydning for å skape et inkluderende og raust samfunn som kan være et viktig vilkår for å fremme god psykisk helse i befolkningen.

\section{Metodiske overveielser}

Studien reiser flere spørsmål knyttet til utvalg og analyse som angår studiens troverdighet og gyldighet, men som også har relevans for diskusjonene omkring normalitet og identitet. La oss se litt på det. Valg av søkeord framstår avgjørende for hele studien, og det er mulig å hevde at utgangspunktet for valget av norske søkeord var for smalt. I en studie om media og psykisk helse argumenterte forskerne for at begrepet "mental hälsa" var mer vanlig på svensk enn "psykisk hälsa" [45]. Dette kan ha begrenset funnene i den svenske delen av utvalget, og samlet sett gitt studien et skjevt utvalg. På den andre siden ble slike skjevheter justert 
gjennom at refererte sider ble inkludert. Dette styrker troverdigheten til studien. Samtidig støtter vi andre forskere som understreker at det nærmest er umulig å få et nøyaktig tall for antall nettsteder [46]. Resultatene fra denne studien kan følgelig best forstås som et bilde av situasjonen i 2009 .

Søkeordene er uansett bestemmende for hva slags fenomener vi undersøker, og spørsmålet blir om funnene kan sies å være gyldige for spørsmål om ungdom og psykisk helse. De Wattignar og Read [35] valgte "depresjon" som et av sine søkeord, og fant en betydelig innflytelse fra den farmasøytiske industrien når det gjaldt finansiering av nettsteder. Vi hadde ventet å finne noe av den samme tendensen, og ble overrasket over den lille innflytelsen fra den farmasøytiske industrien $\mathrm{i}$ vårt materiale. Slik påvirkning kan imidlertid være indirekte og vanskelig å spore, og av den grunn erkjenner vi muligheten for at legemiddelindustrien også kan spille en rolle i denne studien. Det er imidlertid mulig at disse forskjellene kan skyldes valg av søkeord. "Depresjon" er en klinisk medisinsk begrep, og nært knyttet til diagnoser og medikamentell behandling. Det kan forklare den sterke innflytelsen fra privat kapital. "Psykisk helse" er ikke entydig knyttet til det samme konseptet, og dette kan forklare noe av variasjonen.

Ett av kvalitetskravene til kvalitative innholdsanalyser er forventningene om intern homogenitet og ekstern heterogenitet. Det betyr at likhetene innen samme kategori skal være stor, og skillene mellom ulike kategorier klar [47]. Det kan være et tegn på uferdig analysearbeid, dersom medlemmer i en kategori også kan passe $\mathrm{i}$ en annen. I så måte er det mulig å rette kritikk mot denne analysen, og da særlig til kategorien "Informasjon og kontakt med voksne". Denne kategorien framstår som en samlekategori som også kan romme flere nettsteder, og kan derigjennom vitne om en svak ekstern heterogenitet. Det kan i forlengelsen av dette argumenteres for at psykisk helsebegrepet strekkes litt vel langt i denne studien, og at selve begrepet reduseres til et altomfattende og dermed litt innholdsløst begrep både analytisk og praktisk. Verdens helseorganisasjon understreker at forståelsen av psykisk helse er kulturbestemt, og en integrert del i alt folkehelsearbeid [31]. De vegrer seg for å definere begrepet entydig, men har foreslått følgende innholdsavklaring. [Mental health is] "a state of well-being in which the individual realizes his or her own abilities, can cope with the normal stresses of life, can work productively and fruitfully, and is able to make a contribution to his or her community" [31, s. 12]. Ut fra en slik definisjon kan det argumenteres for at også verdens helseorganisasjon opererer med et rimelig åpent og potensielt altomfattende psykisk helsebegrep. Denne undersøkelsen bekrefter samlet sett at ungdoms psykiske helse må forstås bredt. Våre empiriske refleksjoner peker mot at ungdommers psykisk helse i Norge og Sverige er nært forbundet med en kulturell ivaretakelse både av et behov for fellesskap med og avhengighet til andre mennesker, men også av et behov for egenart, selvstendighet og uavhengighet av andre mennesker. Ungdommers psykisk helse blir med andre ord tett knyttet til samfunnets forståelser av normalitet og identitet. Det er av stor interesse å utforske innholdet $\mathrm{i}$ denne brede forståelsen av psykisk helse nærmere.

\section{AvsLutning}

Denne studien viser at psykisk helsearbeid på internett rettet mot ungdom og unge voksne har etablert seg $i$ Norge og Sverige, og drives av virksomheter fra både offentlig og frivillig sektor. Tjenestene fokuserer et mangfold av temaer om ungdom og psykisk helse, men har et tyngdepunkt knyttet til forhold omkring kropp, seksualitet, normalitet og identitet. Nettstedene framstår som et "et skattkammer av problemstillinger som ungdom strever med" (Personlig e-post fra Randi Helen Albertsen ved www.utekontakten.no, 22. april 2009), og utgjør et interessant utgangspunkt for videre studier om ungdom og psykisk helse $\mathrm{i}$ et bredt perspektiv.

\section{REFERANSER}

1. Griffiths F, Lindenmeyer A, Powell J, Lowe P, Thorogood M. Why are health care interventions delivered over the Internet? A systematic review of the published literature. Journal of Medical Internet Research 2006; 8 (2): e10.

2. Ybarra ML, Eaton WW. Internet-based mental health interventions. Mental Health Services Research 2005; 7 (2): 75-87.

3. Andreassen H, Sandaune AG, Gammon D, Hjortdahl, P. Nordmenns bruk av helsetilbud på Internett. Tidsskrift for Den Norske Lageforening 2002; 122 (17): 1640-1644.

4. Kurioka S, Muto T, Tarumi K. Characteristics of health counselling in the workplace via e-mail. Occupational Medicine-Oxford 2001; 51 (7): 427-432.

5. Fukkink RG, Hermanns JM. Children's experiences with chat support and telephone support. Journal of Child Psychology and Psychiatry and Allied Disciplines 2009; 50 (6): 759-766.

6. Sørensen K, Østvik AR, Lintvedt OK, Gammon D, Wang CE. Forebygging av psykisk helse blant studenter ved hjelp av et lavterskeltilbud på Internett. Tidsskrift for Norsk Psykologforening 2007; 44 (3): 265-268. 
7. Richards D. Features and benefits of online counselling: Trinity College online mental health community. British Journal of Guidance \& Counselling 2009; 37 (3): 231-242.

8. Umefjord G, Petersson G, Hamberg K. Reasons for consulting a doctor on the Internet: Web survey of users of an Ask the Doctor service. Journal of Medical Internet Research 2003; 5 (4): e26.

9. Kummervold PE, Gammon D, Bergvik S, Johnsen JAK, Hasvold T, Rosenvinge JH. Social support in a wired world - Use of online mental health forums in Norway. Nordic Journal of Psychiatry 2002; 56 (1): 59-65.

10. Meyer D, Hamel-Lambert J, Tice C, Safran S, Bolon B, Rose-Grippa K. Recruiting and retaining mental health professionals to rural communities: An interdisciplinary course in Appalachia. Journal of Rural Health 2005; 21 (1): 86-91.

11. Griffiths KM, Christensen H. Internet-based mental health programs: A powerful tool in the rural medical kit. Australian Journal of Rural Health 2007; 15 (2): 81-87.

12. Farrell SP, McKinnon CR. Technology and rural mental health. Archives of Psychiatric Nursing 2003; 17 (1): 20-26.

13. Bundorf MK, Wagner, TH, Singer SJ, Baker LC. Who searches the internet for health information? Health Services Research 2006; 41 (3): 819-836.

14. Mehta S, Chalhoub N. An E-mail for your thoughts. Child and Adolescent Mental Health 2006; 11 (3): 168170 .

15. Sheese BE, Brown EL, Graziano WG. Emotional expression in cyberspace: searching for moderators of the Pennebaker disclosure effect via e-mail. Health Psychology 2004; 23 (5): 457-464.

16. Burns J, Morey C, Lagelée A, Mackenzie A, Nicholas J. Reach out! Innovation in service delivery. Medical Journal of Australia 2007; 187 (7): S31-S34.

17. Burns JM, Durkin LA, Nicholas J. Mental health of young people in the United States: what role can the Internet play in reducing stigma and promoting help seeking? Journal of Adolescent Health 2009; 45 (1): 9597.

18. Rickwood DJ, Deane FP, Wilson CJ. When and how do young people seek professional help for mental health problems? Medical Journal of Australia 2007; 187 (7): S35-S39.

19. Ybarra ML, Suman M. Help seeking behavior and the Internet: a national survey. International Journal of Medical Informatics 2006; 75 (1): 29-41.

20. Kassaw K, Gabbard GO. The ethics of e-mail communication in psychiatry. Psychiatric Clinics of North America 2002; 25 (3): 665-674.

21. Valentine G, Holloway SL. Cyberkids? Exploring Children's Identities and Social Networks in On-Line and Off-Line Worlds. Annals of the Association of American Geographers 2009; 92 (2): 302-319.

22. Hall MJ, Tidwell WC. Internet recovery for substance abuse and alcoholism: an exploratory study of service users. Journal of Substance Abuse Treatment 2003; 24 (2): 161-167.

23. Thayer SE, Ray S. Online communication preferences across age, gender, and duration of Internet use. CyberPsychology \& Behaviour 2006; 9 (4): 432-440.

24. Rideout V. Generation Rx.com. What are young people really doing online? Marketing Health Services 2002; 22 (1): $26-30$.

25. Swanton R, Collin P, Burns J, Sorensen I. Engaging, understanding and including young people in the provision of mental health services. International Journal of Adolescent Medical Health 2007; 19 (3): 325332.

26. Aaslestad P. Pasienten som tekst. Oslo: Tano Aschehoug, 1997.

27. Riving C. Icke som en annan människa. Psykisk sjukdom i mötet mellan psykiatrin och lokalsamhället under 1800-talets andra hälft. Hedemora/Möklinta: Gidlunds förlag, 2008.

28. Haave P. Ambisjon og handling. Sanderud sykehus og norsk psykiatri i et historisk perspektiv. Oslo: Unipub, 2008.

29. Andersen AJW. En vanvittig historie. Omsorgen for sinnslidende i Aust-Agder. I: Andersen AJW, Larsen IB, Söderhamn O, red. Utdanning til omsorg - i fortid, nåtid og framtid. Oslo: Gyldendal Akademisk, 2010: 92116.

30. Svensson T. On the notion of mental illness. Problematizing the medical-model conception of certain abnormal behaviours and mental afflictions. Linköping: Linköping Universitet, 1990.

31. WHO. Promoting Mental Health. Consepts, emerging evidence, practice. Summary Report. Geneva: World Health Organization, 2004.

32. Hacking I. Mad travels. Reflections on the reality of transient mental illnesses. London: Free Association Books, 1999.

33. Johannisson K. Hur skapas en diagnos? Et historiskt perspektiv. I: Hallerstedt G, red. Diagnosens makt. Om kunskap, pengar och lidande. Göteborg: Bokförlaget Daidalos, 2006: 29-43.

34. Katsumata Y, Matsumoto T, Kitani M, Takeshima T. Electronic media use and suicidal ideation in Japanese adolescents. Psychiatry and Clinical Neurosciences 2008; 62 (6): 744-746. 
35. de Wattignar S, Read J. The pharmaceutical industry and the internet: Are drug company funded depression websites biased? Journal of Mental Health 2009; 18 (6): 476-485.

36. Carlberg I. Pillret. En berättelse om depressioner och doktorer, forskare och Freud, människor och marknader. Stockholm: Norstedts, 2008.

37. Laake P, Hjartåker A, Thelle DS, Veierød MB. Epidemiologisk og klinisk forskning. I: Laake P, Hjartåker A, Thelle DS, Veierød, MB, red. Epidemiologiske og kliniske forskningsmetoder. Oslo: Gyldendal Akademisk, 2007: 33-45.

38. Bowling A. Research methods in health. Investigating health and health services, $2^{\text {nd }}$ edn. Buckingham Philadelphia: Open University Press, 2002.

39. Graneheim UH, Lundman B. Qualitative content analysis in nursing research: concepts, procedures and measures to achieve trustworthiness. Nurse Education Today 2004; 24: 105-112.

40. Alvesson M, Sköldberg K. Tolkning och reflektion: vetenskapsfilosofi och kvalitativ metod. Lund: Studentlitteratur, 2008.

41. Iwarsson P. Samtal med barn och ungdomar. Erfarenheter från arbetet på BRIS. Stockholm: Gothia Förlag, 2007.

42. Kvalem IL, Wichstrøm L. Ung i Norge: psykososiale utfordringer. Oslo: Cappelen Akademisk forlag, 2007.

43. Nordahl T, Sørlie M-A, Manger T, Tveit A. Atferdsproblemer blant barn og unge. Teoretiske og praktiske tilncerminger. Bergen: Fagbokforlaget, 2005.

44. St.prp. nr. 63 (1997-1998). Om opptrappingsplan for psykisk helse 1999- 2006. Endringer i statsbudsjettet for 1998.

45. Morlandstø L. Medier, makt og psykisk helse. Tidsskrift for psykisk helsearbeid 2010; 7 (2): 110-121.

46. Heinlen KT, Welfeel, ET, Richmond, EN, O'Donnell MS. The nature, scope, and ethics of psychologists' etherapy web sites: What consumers find when surfing the Web. Psychotherapy 2003; 40 (1-2): 112-124.

47. Patton QM. Qualitative research \& evaluation methods, $3^{\text {rd }}$ ed. Thousand Oaks: Sage Publications, 2002. 